\title{
A Review of Colour Phenotypes of the Eastern Red-backed Salamander, Plethodon cinereus, in North America
}

\author{
JEAN-DAVID MOORE ${ }^{1,3}$ and MARTin OuELLET ${ }^{2}$ \\ ${ }^{1}$ Forêt Québec, Ministère des Forêts, de la Faune et des Parcs, Direction de la recherche forestière, 2700 rue Einstein, Québec, \\ Québec G1P 3W8 Canada \\ ${ }^{2}$ Amphibia-Nature, 469 route d'Irlande, Percé, Québec G0C 2L0 Canada \\ ${ }^{3}$ Corresponding author: e-mail: jean-david.moore@mffp.gouv.qc.ca
} Moore, Jean-David, and Martin Ouellet. 2014. A review of colour phenotypes of the Eastern Red-backed Salamander, Plethodon
cinereus, in North America. Canadian Field-Naturalist 128(3): 250-259.

The Eastern Red-backed Salamander (Plethodon cinereus) is the most abundant salamander species in many forests of northeastern North America. It is well-known for its colour polymorphism, which includes eight colour phenotypes: the red-backed (striped), lead-backed (unstriped) and erythristic morphs, as well as the iridistic, albino, leucistic, amelanistic and melanistic anomalies. Here we review the various colorations of $P$. cinereus, with the objective of facilitating the identification of these different phenotypes and of generating interest among field herpetologists and scientists reporting on this species. We also list six previously unpublished occurrences of colour variants in this species ( 1 case of erythrism, 3 of iridism, 1 of leucism, and 1 of partial leucism). To our knowledge, these cases include the first documented occurrence of iridism in the red-backed morph of $P$. cinereus, and the first two mentions of this colour anomaly in the lead-backed morph from Canada.

Key Words: Phenotypes; coloration; red-backed; lead-backed; erythristic; colour morph; iridistic; albino; leucistic; amelanistic; melanistic; colour anomaly; Eastern Red-backed Salamander; Plethodon cinereus; North America

\section{Introduction}

Of all North American amphibians, the Eastern Redbacked Salamander (Plethodon cinereus) is probably one of the most studied species, because of its wide distribution and abundance in forests of eastern Canada and northeastern United States (Highton 1962; Burton and Likens 1975; Petranka 1998), its ecological role (Burton and Likens 1975; Wyman 1998), and its potential as indicator of climatic change (Lotter and Scott 1977; Gibbs and Karraker 2006) and habitat disturbances (deMaynadier and Hunter 1995) in forest ecosystems. Striking colour polymorphism of this salamander species has long attracted the attention of scientists, herpetologists, and naturalists. Three pigment cell classes, or chromatophores, are responsible for skin coloration in amphibians (Bagnara 1966; Taylor and Bagnara 1972): melanophores (brown to black pigment cells), xanthophores (yellow and red (erythrophores) pigment cells), and iridophores, which produce the shiny iridescent and reflecting aspect of the amphibian skin.

In this article, we review the state of knowledge for each of the eight colour phenotypes known to date in $P$. cinereus, which include the red-backed (striped), leadbacked (unstriped) and erythristic morphs, as well as the iridistic, albino, leucistic, amelanistic and melanistic anomalies. Our objective is to provide a standardized description accompanied by photographs for the colour phenotypes reported for $P$. cinereus. Characteristics useful to discriminate among these different phenotypes are summarized. The North American distribution of the different colour morphs and anomalies in P. cinereus is also provided. Finally, we report six previously unpublished phenotype occurrences in this species (1 of ery- thrism, 3 of iridism, 1 of leucism, and 1 of partial leucism).

\section{Colour Morphs}

The red-backed and lead-backed colour morphs

The red-backed and lead-backed morphs (Figure 1) are the two most abundant phenotypes in $P$. cinereus. The ventral body of both morphs is coarsely mottled with black and white, resulting in a distinctive "saltand-pepper" appearance (Figure 2; Table 1; Appendix). Individuals with intermediate colorations or other variations between these two morphs have been observed (e.g., Figure 3; Sipes 1964). The mid-dorsal stripe of the red-backed morph is generally red-orange, with gray-black borders that become mottled with white along the lower half of the body sides. Mid-dorsal stripe colours other than red-orange, such as shades of brown, gray, pink, white, and yellow have also been observed (e.g., Figures 4, 5; Bishop 1941; Test and Bingham 1948; Reed 1955; Schueler 1975; Hulse et al. 2001). Colour variations also include individuals with stripes that occur in disconnected sections along the body, and others with only continuous stripes on the tail (Bishop 1941; Cook 1967; Petranka 1998). The dorsum of the lead-backed morph does not exhibit stripes, and the coloration is generally a uniformly pigmented grayblack, but sometimes olive-gray or chestnut-brown (e.g., Figure 6; Klemens 1993). The dorsal-lateral body often exhibits some degree of iridescent or metallic, blue (Sawyers and Novick 2011), brassy, golden, shades of green or silver flecks (e.g., Figure 7).

Burger (1935) was the first to publish evidence that both morphs could be found in the same brood, which 
TABLE 1. Main characteristics of the 8 colour phenotypes of the Eastern Red-backed Salamander (Plethodon cinereus).

\begin{tabular}{|c|c|c|c|c|}
\hline$\overline{\text { Phenotype }}$ & Dorsal stripe & Dorsal-lateral body & Ventral body & Iris \\
\hline Red-backed & $\begin{array}{l}\text { Continuous or } \\
\text { discontinuous } \\
\text { red-orange stripe; } \\
\text { sometimes shades } \\
\text { of brown, gray, } \\
\text { pink, white or } \\
\text { yellow }\end{array}$ & Gray-black & $\begin{array}{l}\text { "Salt-and-pepper" } \\
\text { appearance }\end{array}$ & $\begin{array}{l}\text { Normal (dark) } \\
\text { pigmentation }\end{array}$ \\
\hline Lead-backed & Unstriped & $\begin{array}{l}\text { Gray-black; sometimes } \\
\text { olive-gray or chestnut-brown }\end{array}$ & $\begin{array}{l}\text { "Salt-and-pepper" } \\
\text { appearance }\end{array}$ & $\begin{array}{l}\text { Normal (dark) } \\
\text { pigmentation }\end{array}$ \\
\hline Erythristic & Unstriped & $\begin{array}{l}\text { Red or orange, with or } \\
\text { without black mottling }\end{array}$ & Red or orange & $\begin{array}{l}\text { Normal (dark) } \\
\text { pigmentation }\end{array}$ \\
\hline Iridistic & $\begin{array}{l}\text { Stripe present } \\
\text { or absent }\end{array}$ & $\begin{array}{l}\text { Generalized iridescent } \\
\text { flecking (brassy, golden, } \\
\text { shades of green or silver) }\end{array}$ & $\begin{array}{l}\text { "Salt-and-pepper" } \\
\text { appearance with or } \\
\text { without iridescent } \\
\text { flecking }\end{array}$ & $\begin{array}{l}\text { Normal (dark) } \\
\text { pigmentation }\end{array}$ \\
\hline Albino & Unstriped & Pink-white to white & $\begin{array}{l}\text { Pink-white to white, } \\
\text { translucent }\end{array}$ & Red-pink \\
\hline Leucistic & Unstriped & Pink-white to white & $\begin{array}{l}\text { Pink-white to white, } \\
\text { translucent }\end{array}$ & $\begin{array}{l}\text { Normal (dark) } \\
\text { pigmentation }\end{array}$ \\
\hline Amelanistic & $\begin{array}{l}\text { Peach-red, orange } \\
\text { or peach-yellow }\end{array}$ & Pink-white to white & $\begin{array}{l}\text { Pink-white to white, } \\
\text { translucent }\end{array}$ & $\begin{array}{l}\text { White to normal } \\
\text { (dark) pigmentation }\end{array}$ \\
\hline Melanistic & Unstriped & Black & Black, translucent & Brown to black \\
\hline
\end{tabular}

showed that they are of the same species (Highton 1959). Both morphs can be found across the species range, throughout southeastern Canada and the eastern United States (Petranka 1998), but in very different proportions (Moore and Ouellet 2014). In some areas, both morphs are abundant, while in others, one or the other is more abundant. Monomorphic red-backed populations are not uncommon, while in other cases, redbacked individuals can be scarce or absent (Thurow 1955; Highton 1959; Pfingsten and Walker 1978; Reichenbach 1981; Fisher-Reid et al. 2013). The redbacked morph has been reported in five Canadian provinces and 22 American states (Table 2), which represents the distribution range of this species. Kentucky, Minnesota, and Tennessee are at the limit of the species' range and the lead-backed morph of $P$. cinereus has not been reported there.

In the last decades, studies have suggested that the lead-backed morph of $P$. cinereus is more closely associated with warmer climates than the red-backed morph (Lotter and Scott 1977; Moreno 1989; Gibbs and Karraker 2006; Anthony et al. 2008). However, it seems that the possible role of climate in the distribution of the lead-backed morph has never been unanimously recognized; some doubts still persist in the scientific community about the validity of using this morph as indicator of climatic changes (Angleberger and Chinnici 1975; Pfingsten and Walker 1978; Petruzzi et al. 2006; Anthony et al. 2008). Based on new discoveries in the northern areas of the species' range and on the largest compilation ever made for this species, Moore and Ouellet (2014) demonstrate however that climate and geographic variables do not influence the colour morph proportions in $P$. cinereus populations. Fitzpatrick et al. (2009) mentioned that the most reasonable hypothesis to explain the existence of visual polymorphism across a geographical and phylogenetic range as wide as that of $P$. cinereus is that selection acts directly on appearance. Local natural selection could explain the morph frequency in given areas.

\section{The erythristic colour morph}

Erythrism (from Greek eruthros, red) refers to an excessive production and deposition of red or orange pigments (erythrophores). The erythristic morph of $P$. cinereus (Figures 8,9 ) is usually all red or orange, but may exhibit varying degrees of black mottling on its dorsal and lateral surfaces. The ventral surface is generally red, orange or pink (Reed 1955; Thurow 1961). Some intermediate colorations (partial erythrism) also exist (e.g., Figure 10). The erythristic morph has been found in four provinces (Brown 1928; Bleakney and Cook 1957; Cook and Bleakney 1961; Rosen 1971) and 10 states (Reed 1908; Reed and Wright 1909; Barbour 1914; Burt 1945; Matthews 1952; Pfingsten 1969; Mueller and Himchak 1983; deMaynadier 1995; McDonald et al. 2011), but it is more frequently found in United States than in Canada. The prevalence of this morph in the United States can sometimes be as high as 35-50\% (Pauley et al. 2001; Cassell and Jones 2005 ), but generally rarely exceeds $20 \%$ (Lotter and Scott 1977; Tilley et al. 1982). According to Pauley et al. (2001), the distribution of this morph would be limited to cooler climates of glaciated areas of southern Canada and the northeastern United States. In this context, the apparent rarity of the erythristic morph in eastern Canada remains enigmatic. Thirty-seven erythristic 


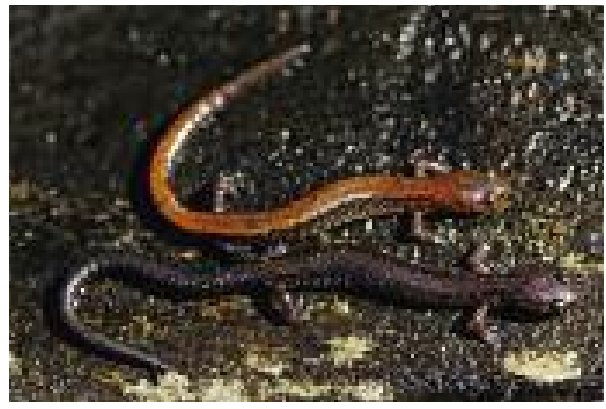

FIGURE 1. Red-backed (striped) and lead-backed (unstriped) morphs of the Eastern Red-backed Salamander (Plethodon cinereus) from Québec. Photo: M. Ouellet.

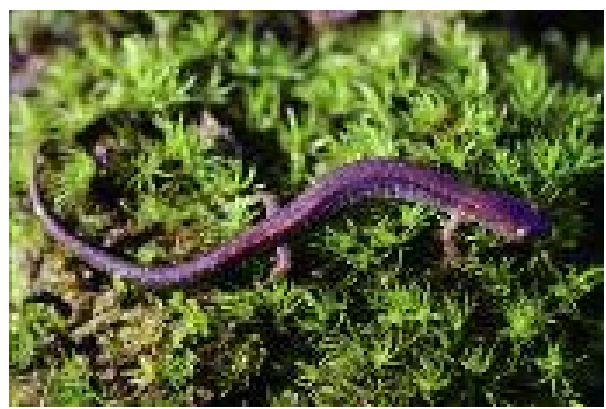

FIGURE 3. Slight colour variation of a red-backed morph of P. cinereus from Québec. Photo: M. Ouellet.

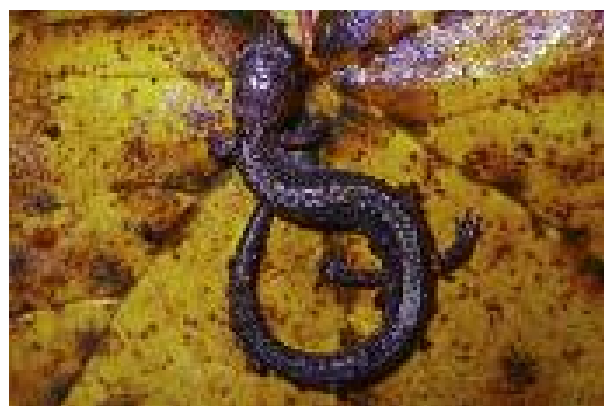

FIGURE 5. Shade of gray coloration of the dorsal stripe of a red-backed morph of $P$. cinereus from Ohio. Photo: C. D. Anthony.

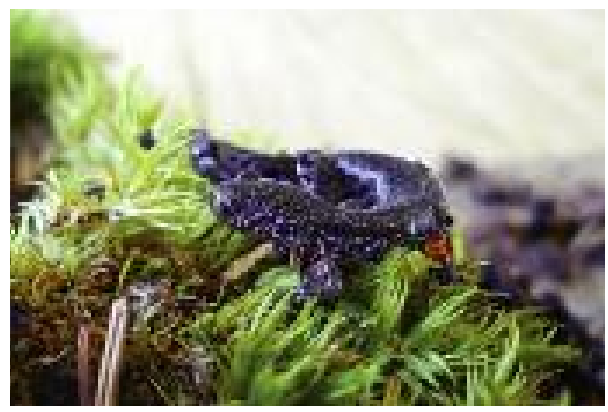

FIGURE 7. A lead-backed morph of $P$. cinereus with blue iridophores from Maine. Photo: D. E. Swann.

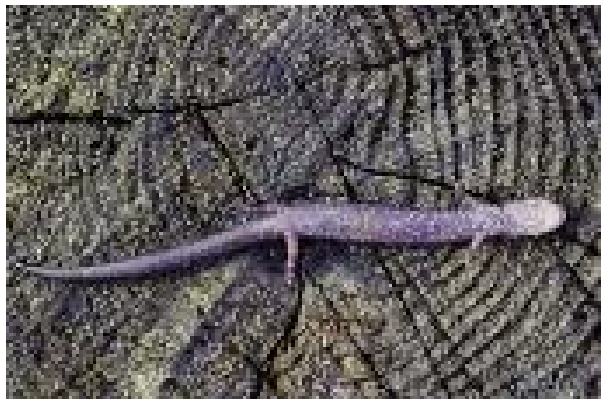

FIGURE 2. Distinctive "salt-and-pepper" appearance of the ventral body of a lead-backed morph of $P$. cinereus from Québec. Photo: M. Ouellet.

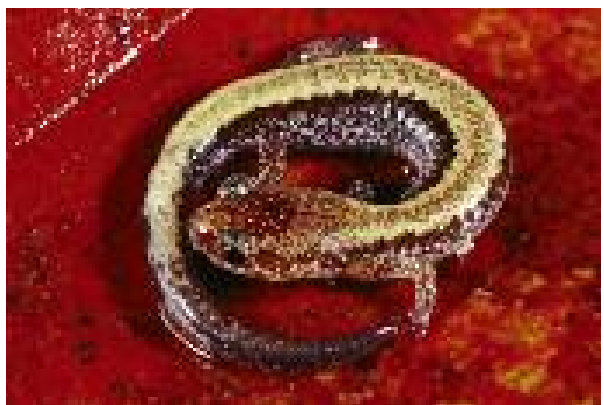

FIGURE 4. Cream coloration of the dorsal stripe of a red-backed morph of $P$. cinereus from New Hampshire. Photo: D. J. Hocking.

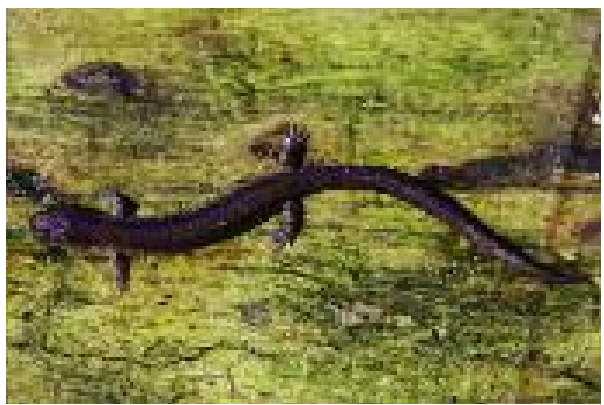

FiguRE 6. Chestnut coloration of a lead-backed morph of P. cinereus from Québec. Photo: M. Ouellet.

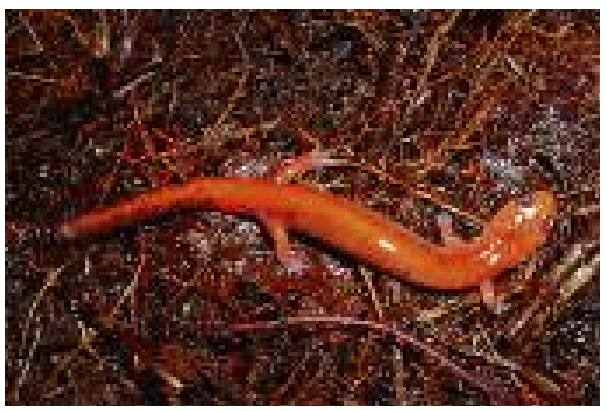

FIGURE 8 . An erythristic morph of $P$. cinereus from Québec. Photo: P. Beaupré. 


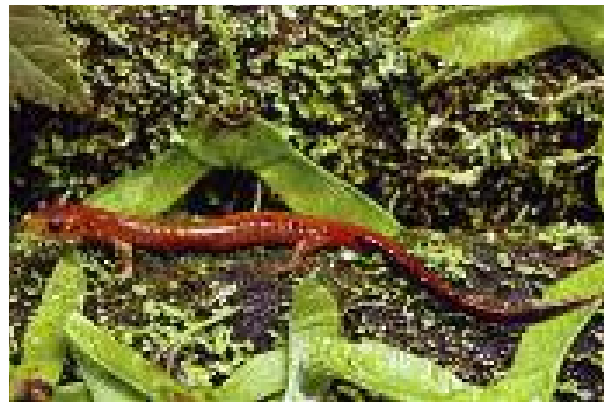

FIGURE 9. Another example of erythrism of $P$. cinereus, with black mottling on the tail, from Nova Scotia. Photo: R. Merrick.

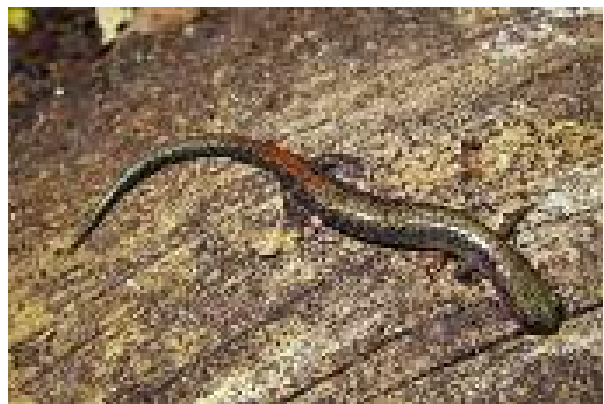

FIGURE 11. An iridistic colour anomaly of a red-backed morph of $P$. cinereus from North Carolina. Photo: L. A. Williams.

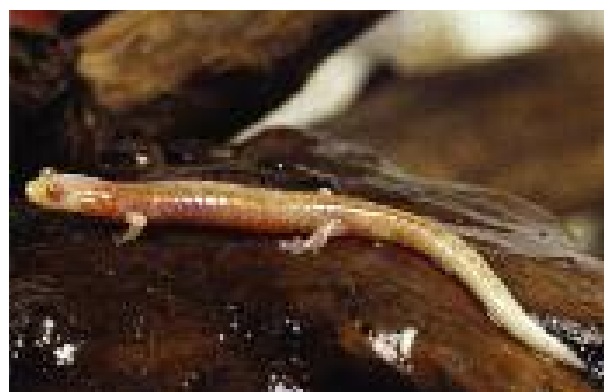

FIGURE 13. An albino colour anomaly of $P$. cinereus from Nova Scotia. Photo: J. Gilhen.

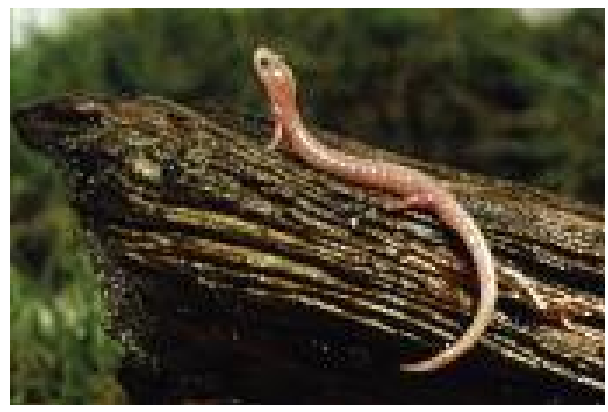

FiguRE 15. Another example of leucism of $P$. cinereus from Nova Scotia. Photo: J. Gilhen.

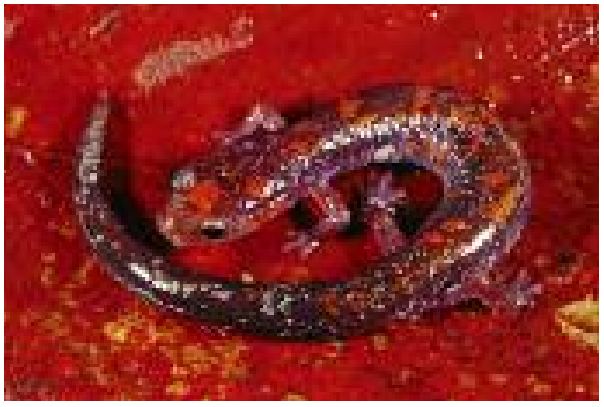

FiguRE 10. A partially erythristic morph of $P$. cinereus from New Hampshire. Photo: D. J. Hocking.

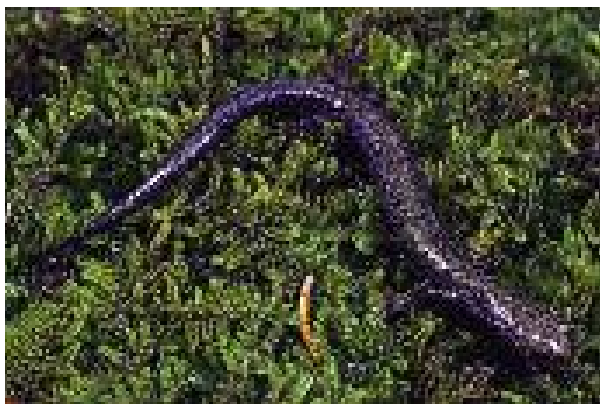

FIGURE 12. Iridism of a lead-backed morph of $P$. cinereus from Nova Scotia. Photo: J. Gilhen.

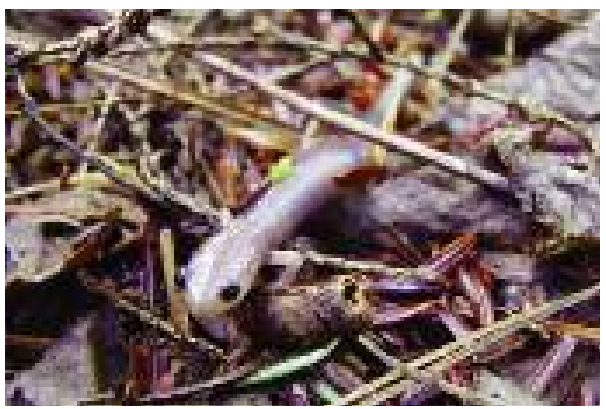

Figure 14. A leucistic colour anomaly of $P$. cinereus from Québec. Photo: L. Bouthillier.

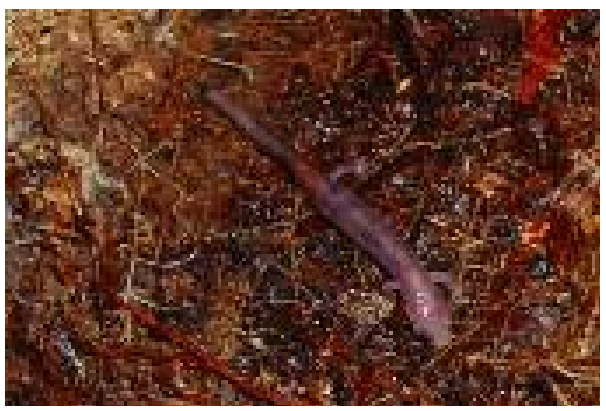

FIGURE 16. Dorsal view of a partially leucistic $P$. cinereus from Québec. Photo: P. Beaupré 


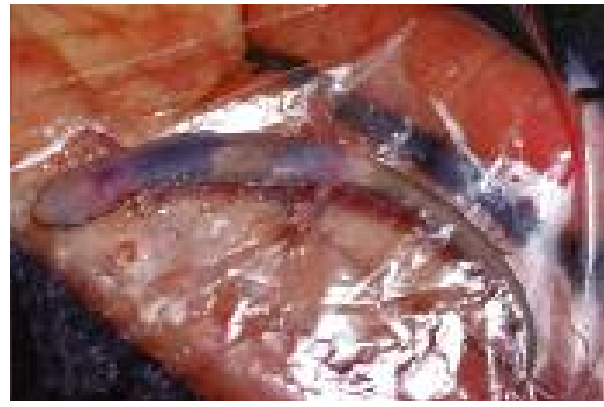

FIGURE 17. Ventral view of the previous specimen of a partially leucistic $P$. cinereus, showing the translucent aspect of the body. Photo: P. Beaupré.

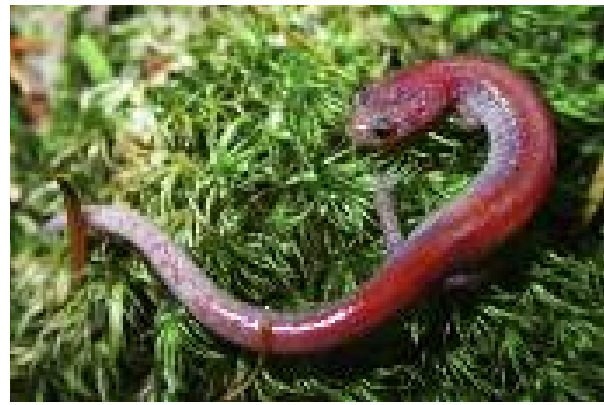

FIgURE 19. An amelanistic colour anomaly of $P$. cinereus from Québec. Photo: J.-D. Moore.

individuals have been reported in Canada (e.g., Piersol 1909; Gilhen 1968; Rosen 1971; Westell and Ross 1974; Jongsma 2012a), including a new occurrence for Québec (Figure 8). This specimen was observed in October 2005 in the La Haute-Yamaska Regional County Municipality, Québec $\left(45^{\circ} 21^{\prime} 20^{\prime \prime} \mathrm{N}, 72^{\circ} 37^{\prime} 18^{\prime \prime} \mathrm{W}\right.$; datum = NAD83). Jongsma (2012a) reported 11 erythristic individuals among 85 P. cinereus specimens in Fredericton, New Brunswick, thus demonstrating that some salamander populations in eastern Canada could nevertheless show a high prevalence of erythrism.

Thurow (1955) mentioned that the nature of the erythristic form and its distribution suggest that genetic rather than environmental factors are involved. According to his interpretation, this phenotype could result from the action of a mutant allele that quantitatively inhibits the development of melanin (or possibly melanophores). For intermediate colorations of this morph, the author noted the possibility of only partial dominance or the involvement of more than one locus. Other studies suggested that erythristic $P$. cinereus may be the Batesian mimic of the Eastern Newt (Notophthalmus viridescens) at the elf stage (Lotter and Scott 1977; Tilley et al. 1982; Cassell and Jones 2005), which is known to be toxic for potential predators (Brodie et al. 1974). This phenomenon would partly explain the high abundance of the erythristic morph in some forests where the red eft is present. However, the presence of the red eft in northern forests does not necessarily imply

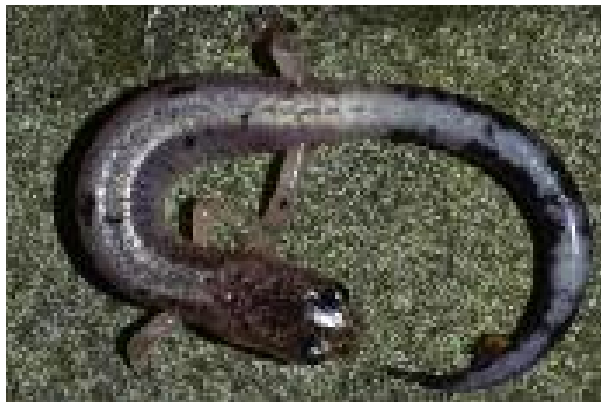

FIGURE 18 . A partially leucistic $P$. cinereus from Ohio. Photo: C. D. Anthony.

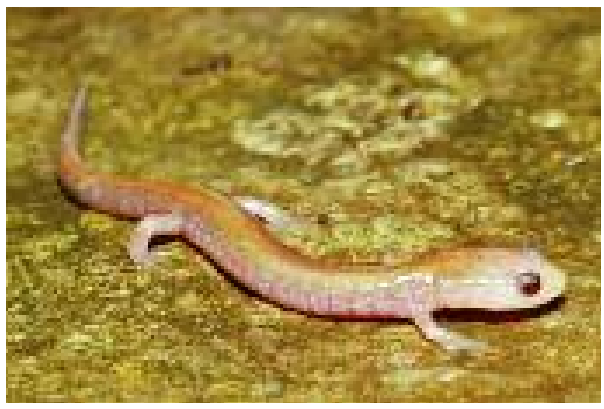

FIGURE 20. Another example of amelanism of $P$. cinereus from Ohio (the red-eye effect is due to the photographic flash). Photo: J. G. Davis.

that the erythristic morph will be found in these ecosystems (Moore et al. 2012).

\section{Colour Anomalies}

\section{The iridistic colour anomaly}

Iridism in amphibians is defined as the excessive production and deposition of iridophore platelets. Individuals are characterized by generalized iridescent or metallic, brassy, golden, shades of green or silver flecks on their dorsal-lateral body. This condition has previously been described (Muchmore 1955; Hertzler 1958) and reported for the lead-backed morph of $P$. cinereus in the United States (Bogert 1952; Highton 1962, 1972; Schueler 1975; Klemens 1993; Hulse et al. 2001; Gibbs et al. 2007). However, it was not always clear from these documents whether the iridescent flecking was very abundant or visible only upon close examination. Muchmore (1955) noted that microscopic examination revealed that this flecking was due to numerous individual iridophores located around the melanophores. These flecks are also known to fade rapidly on preserved specimens (Grobman 1949; Muchmore 1955; Pfingsten and Downs 1989).

We report here three previously unpublished occurrences of iridistic $P$. cinereus, including, to our knowledge, the first documented occurrence of iridism in the red-backed morph and the first two mentions in lead-backed morphs from Canada. In all these cases, the dorsal body exhibited abundant, continuous, and 
TABLE 2. North American distribution of the 8 different colour morphs and anomalies of the Eastern Red-backed Salamander (Plethodon cinereus). Abbreviations: Red = red-backed morph, Lea = lead-backed morph, Ery = erythristic morph, Iri = iridistic anomaly, Alb = albino anomaly, Leu = leucistic anomaly, Ame = amelanistic anomaly, Mel = melanistic anomaly.

\begin{tabular}{|l|l|l|l|l|l|l|l|l|}
\hline \hline Province or State & Red & Lea & Ery & Iri & Alb & Leu & Ame & Mel \\
\hline Connecticut & & & & & & & & \\
\hline Delaware & & & & & & & & \\
\hline Illinois & & & & & & & & \\
\hline Indiana & & & & & & & & \\
\hline Kentucky & & & & & & & & \\
\hline Maine & & & & & & & & \\
\hline Maryland & & & & & & & & \\
\hline Massachusetts & & & & & & & & \\
\hline Michigan & & & & & & & & \\
\hline Minnesota & & & & & & & & \\
\hline New Brunswick & & & & & & & & \\
\hline New Hampshire & & & & & & & & \\
\hline New Jersey & & & & & & & & \\
\hline New York & & & & & & & & \\
\hline North Carolina & & & & & & & & \\
\hline Nova Scotia & & & & & & & & \\
\hline Ohio & & & & & & & & \\
\hline Ontario & & & & & & & & \\
\hline Pennsylvania & & & & & & & & \\
\hline Prince Edward Island & & & & & & & & \\
\hline Québec & & & & & & & \\
\hline Rhode Island & & & & & & & \\
\hline Tennessee & & & & & & & \\
\hline Vermont & & & & & & & \\
\hline Virginia & & & & & & & \\
\hline West Virginia & & & & & & & \\
\hline Wisconsin & & & & & & & & \\
\hline \hline
\end{tabular}

large iridescent brassy flecks. The first individual (Figure 11) was observed in September 2012 in Ashe County, North Carolina $\left(36^{\circ} 25^{\prime} 35^{\prime \prime} \mathrm{N}, 81^{\circ} 35^{\prime} 26^{\prime \prime} \mathrm{W}\right.$; datum $=$ WGS84), and the second (Figure 12) was reported in June 1982 in Colchester County, Nova Scotia $\left(45^{\circ} 23^{\prime} 37^{\prime \prime} \mathrm{N}, 63^{\circ} 55^{\prime} 04^{\prime \prime} \mathrm{W}\right.$; datum = NAD83 $)$. The third specimen was observed in October 2013 in the Antoine-Labelle Regional County Municipality, Québec $\left(46^{\circ} 43^{\prime} 03^{\prime \prime} \mathrm{N}, 75^{\circ} 33^{\prime} 06^{\prime \prime} \mathrm{W}\right.$; datum = NAD83). These occurrences show that iridescent flecking is sometimes quite abundant and may represent the dominant colour in some $P$. cinereus individuals. Added with cases from other studies (e.g., Muchmore 1955), they also suggest that iridism in $P$. cinereus is probably more common than previously reported, and thus deserves to be regarded as a noteworthy colour variant. To date, it has been reported in two provinces and 9 states (Table 2).

\section{The albino colour anomaly}

Albinism (from Latin albus, white) is defined as the total absence of pigmentation formation in the skin and irises. The albino $P$. cinereus is unstriped and characterized by a flesh-colored body (pink-white to white) and red-pink irises (Figure 13). According to the literature, this anomaly has been observed three times in
Canada (Milnes 1946; Moore et al. 2012) and three times in the United States (Fowler 1942; Hensley 1959; Harris 1968a), though no detailed description of the specimens was given by Milnes (1946) nor Harris (1968a). The only case mentioned in Québec (Moore et al. 2012) has been redefined as an amelanistic $P$. cinereus, after the photographic verification showed normal (dark) pigmentation of the irises, a light orange dorsal stripe and the pink-white colour of the specimen's dorsal-lateral body. Similarly, the albino case reported by Harris (1968b) was redefined as an amelanistic, based on a published photograph (Zahl 1972).

\section{The leucistic colour anomaly}

Leucism (from Greek leukos, white) is a defect in the skin causing an inability to support any type of skin pigments. Since all types of skin pigments are thus reduced, leucistic individuals resemble albino $P$. cinereus (Figures 14, 15), except for their normally pigmented irises. This explains why this condition has also been defined in the past as "albinos with orbital melanophores" (Brame 1962), or "partial albinos" (Gilhen 1986). The leucistic anomaly has been observed four times in Canada (Gilhen 1986 (based on the colour photo NSM973-634-1); Rye 1991; Lamond 1994; Jongsma 2012b) and six times in the United States (Wilmott 
1945; Pauley 1974; Lotter and Scott 1977 (white partial albino); Mitchell and Mazur 1998; Mendyk et al. 2010). A previously unpublished occurrence of leucism (Figure 14) was observed in September 2013 in the Thérèse-De Blainville Regional County Municipality, Québec (45³9'28"N, 7354'33"W; datum = NAD83). An unpublished occurrence of partial leucism (Figures 16, 17) was also reported in September 2005 in the Nouvelle-Beauce Regional County Municipality, Québec $\left(46^{\circ} 32^{\prime} 30^{\prime \prime} \mathrm{N}, 71^{\circ} 00^{\prime} 01^{\prime \prime} \mathrm{W}\right.$; datum = NAD83). Leucism was considered as partial in this specimen, due to the presence of melanophores. Two similar cases have also been described in Ohio (Figure 18, Paluh et al. 2013).

\section{The amelanistic colour anomaly}

Amelanism is a condition characterized by the lack of melanin production. The appearance of this anomaly on the skin depends on the remaining non-melanin pigments. Although similar, amelanistic $P$. cinereus salamanders may retain more coloration than the albino and leucistic anomalies, and are characterized by a body without black pigmentation (Figures 19, 20). The dorsal stripe is typically pale in colour, usually peach-red, orange or peach-yellow. The dorsal-lateral body is often pink-white to white, the ventral body is sometimes translucent, and the iris colour may vary from white to normal (dark).

This colour anomaly has been reported five times in eastern Canada (Gilhen 1986 (based on the colour photo NSM984-108-1); Moore and Gilhen 2011; Russell et al. 2011; see also the above section on the albino anomaly), and twice in the United States (Davis 2009; see also the above section on the albino anomaly). Some authors may sometimes have considered the amelanistic condition as partial albinism, using terminology such as "albinos with xanthophores" or "partial albino with xanthophores" and "albinos with erythrophores" or "partial albino with erythrophores" (Brame 1962; Harris 1970; Dyrkacz 1981).

\section{The melanistic colour anomaly}

Melanism (from Greek melas, black) is a condition characterized by an overabundance of melanin pigments (melanophores) production and deposition. Melanistic individuals are usually totally black, including the ventral body and irises. This condition is somewhat the opposite of amelanism. This anomaly in a $P$. cinereus was first mentioned in Québec (Moore et al. 2012). With its uniformly black and translucent belly, the melanistic individual is relatively easy to distinguish from the lead-backed morph (occasionally very dark), which has a salt-and-pepper belly appearance. The melanistic anomaly is not new and has already been encountered in other salamander and anuran species, in which the ventral body is sometimes translucent (Dubois, 1979).

\section{Conclusion}

Eight colour phenotypes of the woodland salamander $P$. cinereus have been reported to date. These include main colour morphs as well as rarer colour anomalies. To discriminate among these different phenotypes, useful characteristics are summarized in Table 1 , and a dichotomous key is provided (Appendix). Contrary to amphibian malformations that are mostly found in young individuals and rarely in adults because they are maladaptive (Ouellet 2000), most of the $P$. cinereus specimens encountered that exhibit colour anomalies are adults. We agree with Mendyck et al. (2010) that these colour conditions may be less detrimental for this secretive species than for other amphibians, and thus more likely to be present.

We hope that this article and the greater accessibility of digital photography will encourage documenting these atypical cases in future inventories. We suggest using uniform colour names based on an easily-accessible online list of colours (Wikipedia 2014). This list is preferred over other guides (e.g., Smithe 1975) which are rather more difficult to obtain. An ongoing colour photo gallery is currently online for recognition and comparison purposes (http://www.amphibia-nature.org /en/projects/amphibians-reptiles/colorations-plethodon/). Photos of unusual colorations with the date, location, and details about the observation can be sent to the following address: info@amphibia-nature.org. Closeup pictures that show the colour of the dorsal stripe, dorsal-lateral body, ventral body, and irises are preferred.

\section{Acknowledgements}

We are grateful to all photographers who kindly contributed pictures of $P$. cinereus to illustrate this article: C. D. Anthony (John Carroll University); P. Beaupré (Ministère du Développement durable, de l'Environnement, de la Faune et des Parcs du Québec); L. Bouthillier (Ministère du Développement durable, de l'Environnement, de la Faune et des Parcs du Québec); J. G. Davis (Cincinnati Museum Center); J. Gilhen (Nova Scotia Museum of Natural History); D. J. Hocking (University of New Hampshire); R. Merrick; D. E. Swann; and L. A. Williams (North Carolina Wildlife Resources Commission). We also acknowledge C. Genest (Amphibia-Nature) for sharing her field observations, P. Galois (Amphibia-Nature) and D. Tousignant (Forêt Québec) for reviewing an earlier version of this manuscript, J. G. Davis for some museum data contribution, and J. T. Bagnara (Professor Emeritus, University of Arizona), F. R. Cook (Canadian Museum of Nature), J. Gilhen, T. B. Persons (USGS Southwest Biological Science Center) and F. W. Schueler (Bishops Mills Natural History Centre) for helpful comments.

\section{Literature Cited}

Angleberger, M. A. P., and J. P. Chinnici. 1975. Dimorphism in the redbacked salamander Plethodon cinereus (Green) at Mountain Lake, Virginia. Virginia Journal of Science 26: 153-158.

Anthony, C. D., M. D. Venesky, and C. M. Hickerson. 2008. Ecological separation in a polymorphic terrestrial salamander. Journal of Animal Ecology 77: 646-653. 
Bagnara, J. T. 1966. Cryptology and cryptophysiology of non-melanophore pigment cells. International Review of Cytology 20: 173-205.

Barbour, T. 1914. An unusual red salamander. Copeia 1914: 3-4.

Bishop, S. C. 1941. The salamanders of New York. New York State Museum Bulletin 324: 1-365.

Bleakney, J. S., and F. R. Cook. 1957. Two erythristic Plethodon cinereus from Nova Scotia. Copeia 1957: 143.

Bogert, C. M. 1952. Relative abundance, habitats, and normal thermal levels of some Virginia salamanders. Ecology 33: 16-30.

Brame, A. H., Jr. 1962. A survey of albinism in salamanders. Abhandlungen und Berichte für Naturkunde und Vorgeschichte 11: 65-81.

Brodie, E. D., Jr, J. L. Hensel, and J. A. Johnson. 1974. Toxicity of the urodele amphibians Taricha, Notophthalmus, Cynops, and Paramesotriton (Salamandridae). Copeia 1974: 506-511.

Brown, J. R. 1928. The herpetology of Hamilton, Ontario, and District. Canadian Field-Naturalist 1928: 125-127.

Burger, J. W. 1935. Plethodon cinereus (Green) in eastern Pennsylvania and New Jersey. American Naturalist 69: 578-586.

Burt, C. E. 1945. A mutant red-phase wood salamander (Plethodon cinereus) from New Hampshire. Transactions of the Kansas Academy of Science 48: 204.

Burton, T. M., and G. E. Likens. 1975. Salamander populations and biomass in the Hubbard Brook Experimental Forest, New Hampshire. Copeia 1975: 541-546.

Cassell, R. W, and M. P. Jones. 2005. Syntopic occurrence of the erythristic morph of Plethodon cinereus and Notophthalmus viridescens in Pennsylvania. Northeastern Naturalist 12: 169-172.

Cook, F. R. 1967. An analysis of the herpetofauna of Prince Edward Island. National Museums of Canada Bulletin 212: $1-60$.

Cook, F. R., and J. S. Bleakney. 1961. Red phase of the redbacked salamander from New Brunswick. Canadian FieldNaturalist 75: 53.

Davis, J. G. 2009. Plethodon cinereus (Eastern red-backed salamander). Coloration. Herpetological Review 40: 197.

deMaynadier, P. G. 1995. Plethodon cinereus cinereus (Redback salamander). Coloration. Herpetological Review 26: 199.

deMaynadier, P. G., and M. L. Hunter, Jr. 1995. The relationship between forest management and amphibian ecology: A review of the North American literature. Environmental Reviews 3: 230-261.

Dubois, A. 1979. Anomalies and mutations in natural populations of the Rana "esculenta" complex (Amphibia, Anura). Mitteilungen aus dem Zoologischen Museum in Berlin 55: 59-87.

Dyrkacz, S. 1981. Recent instances of albinism in North American amphibians and reptiles. SSAR Herpetological Circular 11: 1-31.

Fisher-Reid, M. C., T. N. Engstrom, C. A. Kuczynski, P. R. Stephens, and J. J. Wiens. 2013. Parapatric divergence of sympatric morphs in a salamander: Incipient speciation on Long Island? Molecular Ecology 22: 4681-4694.

Fitzpatrick, B. M., K. Shook, and R. Izally. 2009. Frequency-dependent selection by wild birds promotes polymorphism in model salamanders. BMC Ecology 9: 12.

Fowler, J. A. 1942. Herpetological notes from Lake Cobbosseecontee and vicinity, Kennebec County, Maine. Copeia 1942: 185-186.
Gibbs, J. P., A. R. Breisch, P. K. Ducey, G. Johnson, J. L. Behler, and R. C. Bothner. 2007. The Amphibians and Reptiles of New York State: Identification, Natural History, and Conservation. Oxford University Press, USA.

Gibbs, J. P., and N. E. Karraker. 2006. Effects of warming conditions in eastern North American forests on red-backed salamander morphology. Conservation Biology 20: 913917.

Gilhen, J. 1968. Eight erythristic Plethodon cinereus cinereus (Green) from Poison Lake area, Cumberland County, Nova Scotia. Canadian Field-Naturalist 82: 53-54.

Gilhen, J. 1986. Two partial albino eastern redback salamanders, Plethodon cinereus, in Nova Scotia. Canadian FieldNaturalist 100: 375.

Grobman, A. B. 1949. Some recent collections of Plethodon from Virginia with the description of a new form. Proceedings of the Biological Society of Washington 62: 135142.

Harris, H. S. 1968a. A survey of albinism in Maryland amphibians and reptiles. Bulletin of the Maryland Herpetological Society 4: 57-60.

Harris, H. S. 1968b. Additional albino amphibians and reptiles from Maryland. Bulletin of the Maryland Herpetological Society 4: 88-89.

Harris, H. S. 1970. Abnormal pigmentation in Maryland amphibians and reptiles. Bulletin of the Maryland Herpetological Society 6: 21-27.

Hensley, M. 1959. Albinism in North American amphibians and reptiles. Museum of Michigan State University, Biological Series 1: 135-159.

Hertzler, E. C. 1958. The red and black phases of the salamander Plethodon cinereus. Physiological Zoology 31: 248-256.

Highton, R. 1959. The inheritance of the color phases of Plethodon cinereus. Copeia 1959: 33-37.

Highton, R. 1962. Revision of North American salamanders of the genus Plethodon. Bulletin of the Florida State Museum 6: 235-367.

Highton, R. 1972. Distributional interactions among eastern North American salamanders of the genus Plethodon. Pages 139-188 in The Distributional History of the Biota of the Southern Appalachians Part III: Vertebrates. Edited by P. C. Holt, R. A. Paterson, and J. P. Hubbard. Virginia Polytechnic Institute and State University, Blacksburg, Virginia.

Hulse, A. C., E. Censky, and C. J. McCoy. 2001. Amphibians and Reptiles of Pennsylvania and the Northeast. First edition. Comstock Publishing Associates, USA.

Jongsma, G. F. M. 2012a. Plethodon cinereus (Eastern redbacked salamander). Morphology. Herpetological Review 43: 318.

Jongsma, G. F. M. 2012b. Plethodon cinereus (Eastern redbacked salamander). Morphology. Herpetological Review 43: 460.

Klemens, M. W. 1993. The amphibians and reptiles of Connecticut and adjacent regions. State Geological and Natural History Survey of Connecticut. Bulletin 112: 1-318.

Lamond, W. G. 1994. The Reptiles and Amphibians of the Hamilton Area: A Historical Summary and the Results of the Hamilton Herpetofaunal Atlas. Hamilton Naturalists' Club, Ontario, Canada.

Lotter, F., and N. J. Scott, Jr. 1977. Correlation between climate and distribution of the color morphs of the salamander Plethodon cinereus. Copeia 1977: 681-690.

Matthews, E. 1952. Erythrism in the salamander Plethodon cinereus cinereus. Copeia 1952: 277. 
McDonald, M. L., L. J. Kirschman, and K. J. Regester. 2011. Plethodon cinereus (Red-backed salamander). Erythristic morph. Herpetological Review 42: 405-406.

Mendyck, R. W., L. Augustine, and G. Montague. 2010. Plethodon cinereus (Red-backed salamander). Leucism. Herpetological Review 41: 189-190.

Milnes, H. 1946. Amphibians and reptiles of Oxford County, Ontario. Canadian Field-Naturalist 60: 1-4.

Mitchell, J. C., and J. Mazur. 1998. Leucistic red-backed salamanders (Plethodon cinereus) from Maryland. Northeastern Naturalist 5: 367-369.

Moore, J.-D., and J. Gilhen. 2011. Two amelanistic eastern red-backed salamanders (Plethodon cinereus) from eastern Canada. Canadian Field-Naturalist 125: 58-60.

Moore, J.-D., J. Gilhen, and M. Ouellet. 2012. Phénotypes de la salamandre cendrée (Plethodon cinereus) dans le nord-est de l'Amérique du Nord. Naturaliste Canadien 136(3): 69-72.

Moore, J.-D., and M. Ouellet. 2014. Questioning the use of an amphibian colour morph as an indicator of climate change. Accepted in Global Change Biology.

Moreno, G. 1989. Behavioral and physiological differentiation between the color morphs of the salamander, Plethodon cinereus. Journal of Herpetology 23: 335-341.

Muchmore, W. B. 1955. Brassy flecking in the salamander Plethodon c. cinereus, and the validity of Plethodon huldae. Copeia 1955: 170-172.

Mueller, C. F., and M. Himchak. 1983. Plethodon cinereus. Coloration. Herpetological Review 14: 72-73.

Ouellet, M. 2000. Amphibian deformities: Current state of knowledge. Pages 617-661 in Ecotoxicology of Amphibians and Reptiles, Edited by D. W. Sparling, G. Linder, and C. A. Bishop, Society of Environmental Toxicology and Chemistry, Pensacola, Florida.

Paluh, D. J., C. D. Anthony, and C.-A. M. Hickerson. 2013. Plethodon cinereus (Eastern red-backed salamander). Morphology. Herpetological Review 44: 652-653.

Pauley, T. K. 1974. A leucistic Plethodon cinereus from West Virginia. Restart 41: 104.

Pauley, T. K., J. C. Mitchell, and M. B. Watson. 2001. The first reported population of the erythristic morph of Plethodon cinereus in Pennsylvania. Northeastern Naturalist 8: 355-358.

Petranka, J. W. 1998. Salamanders of the United States and Canada. Smithsonian Institution Press, Washington, USA.

Petruzzi, E. E., P. H. Niewiarowski, and F. B.-G. Moore. 2006. The role of thermal niche selection in maintenance of a colour polymorphism in redback salamanders (Plethodon cinereus). Frontiers in Zoology 3: 10, doi:10.1186 /1742-9994-3-10.

Pfingsten, R. A. 1969. An erythristic population of Plethodon cinereus in Ohio. Journal of Herpetology 3: 104-105.

Pfingsten, R. A., and F. L. Downs. 1989. Salamanders of Ohio. Ohio Biological Survey Bulletin, New Series 7: 1-315.

Pfingsten, R. A., and C. F. Walker. 1978. Some nearly all black populations of Plethodon cinereus (Amphibia, Urodela, Plethodontidae) in northern Ohio. Journal of Herpetology 12: 163-167.

Piersol, W. H. 1909. The habits and larval state of Plethodon cinereus erythronotus. Transactions of the Royal Canadian Institute 8: 469-493.
Reed, C. F. 1955 . Notes on salamanders from western Connecticut, with special reference to Plethodon cinereus. Copeia 1955: 253-254.

Reed, H. D. 1908. A note on the coloration of Plethodon cinereus. American Naturalist 17: 460-465.

Reed, H. D., and A. H. Wright. 1909. The vertebrates of the Cayuga Lake basin, N. Y. Proceedings of the American Philosophical Society 48: 370-459.

Reichenbach, R. G. 1981. Plethodon cinereus (Redback salamander). Coloration. Herpetological Review 12: 79.

Rosen, M. 1971. An erythristic Plethodon cinereus cinereus from Ste. Foy, Portneuf County, Québec. Canadian FieldNaturalist 85: 326-327.

Russell, R. W., W. Beslin, M. Hudak, A. Ogunbiyi, A. Withrow, and J. Gilhen. 2011. A second amelanistic eastern red-backed salamander, Plethodon cinereus, from Nova Scotia, Canada. Canadian Field-Naturalist 125: 359-362.

Rye, L. A. 1991. A leucistic eastern redback salamander, Plethodon cinereus, and an albinistic yellow-spotted salamander, Ambystoma maculatum, from southern Ontario. Canadian Field-Naturalist 105: 573-574.

Sawyers, M. S., and C. M. J. Novick. 2011. Plethodon cinereus (Eastern red-backed salamander). Color variation. Herpetological Review 42: 580-581.

Schueler, P. W. 1975. Colour morphs of Plethodon cinereus in New England and New York. Engelhardtia 6: 16-22.

Sipes, M. P. 1964. A Distributional Survey of the Salamanders Inhabiting Northeastern Ohio. M.Sc. Dissertation, Kent State University, USA.

Smithe, F. B. 1975. Naturalist's Color Guide. American Museum of Natural History, New York, USA.

Taylor, J. D., and J. T. Bagnara. 1972. Dermal chromatophores. American Zoologist 12: 43-62.

Test, F. H., and B. A. Bingham. 1948. Census of a population of the red-backed salamander (Plethodon cinereus). American Midland Naturalist 39: 362-372.

Thurow, G. R. 1955. Taxonomic and Ecological Studies on the Zig-zag Salamander (Plethodon dorsalis) and the Redbacked Salamander (Plethodon cinereus). Ph.D. Dissertation, Indiana University, USA.

Thurow, G. R. 1961. A salamander color variant associated with glacial boundaries. Evolution 15: 281-287.

Tilley, S. G., B. L. Lundrigin, and L. P. Brower. 1982. Erythrism and mimicry in the salamander Plethodon cinereus. Herpetologica 38: 409-417.

Westell, P. A., and F. D. Ross. 1974. Erythristic red-backed salamanders, Plethodon cinereus, from Ontario. Canadian Field-Naturalist 88: 231-232.

Wikipedia. 2014. List of colors. Accessed 11 March 2014. http://en.wikipedia.org/wiki/List_of_colors.

Wilmott, G. B. 1945. Something about salamanders. Animaland (Staten Island Zoological Society) 12: 1-2.

Wyman, R. L. 1998. Experimental assessment of salamanders as predators of detrital food webs: Effects on invertebrates, decomposition and the carbon cycle. Biodiversity and Conservation 7: 641-650.

Zahl, P. A. 1972. The shadowy world of salamanders. National Geographic 142(1): 104-116.

Received 27 March 2014

Accepted 24 April 2014 


\section{Appendix}

Dichotomous key of the 8 different colour phenotypes of the Eastern Red-backed Salamander (Plethodon cinereus).

1.a Presence of a continuous or discontinuous dorsal stripe: 2

1.b Absence of a dorsal stripe: 4

2.a Presence of melanophores on the skin surface: 3

2.b Absence of melanophores, dorsal-lateral body pink-white to white: Amelanistic anomaly (Figures 19, 20)

3.a Generalized iridescent flecking: Iridistic anomaly (Figure 11)

3.b No generalized iridescent flecking: Red-backed morph (Figures 1-5)

4.a Presence of melanophores on the skin surface: 5

4.b Absence of skin melanophores: 8

5.a Presence of red or orange pigmentation: Erythristic morph (Figures 8-10)

5.b Absence of red pigmentation: 6

6.a "Salt-and-pepper" appearance of the ventral body: 7

6.b Black and translucent ventral body: Melanistic anomaly

7.a Generalized iridescent flecking: Iridistic anomaly (Figure 12)

7.b No generalized iridescent flecking: Lead-backed morph (Figures 1, 2, 6, 7)

8.a Red-pink pigmentation of the irises: Albino anomaly (Figure 13)

8.b Normal (dark) pigmentation of the irises: Leucistic anomaly (Figures 14-18) 